\title{
Tracing the evolution of the global marine redox conditions from the Late Ediacaran to Early Cambrian: Clues from vanadium isotopes
}

\author{
WEI WEI ${ }^{1}$ AND FANG HUANG ${ }^{2}$ \\ ${ }^{1}$ University of Science and Technology of China \\ ${ }^{2}$ CAS Key Laboratory of Crust-Mantle Materials and \\ Environments, School of Earth and Space Sciences, University \\ of Science and Technology of China
}

Presenting Author: wwei1@ustc.edu.cn

The Late Ediacaran to Early Cambrian whitnessed multiplephase radiations and extinctions of metazoans, leading up to the "Cambrian Explosion". Variations in marine redox conditions may have played an essential role on this evolutionary event. However, detailed spatial distribution and temporary evolution of marine redox conditions during this period remain unclear and controversial. Vanadium (V) isotopes are an emerging proxy that has shown potential to trace rapid evolutions in the global marine redox conditions. In this study, we analyzed $\mathrm{V}$ isotope compositions $\left(\delta^{51} \mathrm{~V}\right)$ of the organic-rich cherts and black shales from the fouth member of the Doushantuo Formation (DST-IV) at the Jiulongwan section and from the Liuchapo and Niutitang Formations at the Longbizui section. All the $\delta^{51} \mathrm{~V}$ show large variations, from $-1.03 \%$ to $-0.52 \%$ in the DST-IV, from $-0.77 \%$ o to $-0.49 \%$ in the Liuchapo Formation, and from -0.44 to $-0.16 \%$ in the Niutitang Formation. There is a good positive correlation between the $\delta^{51} \mathrm{~V}$ and previously published $\delta^{98} \mathrm{Mo}[1]\left(\mathrm{R}^{2}=0.7\right.$, $n=20$ ). This indicates that the geochemical cycle of $\mathrm{V}$ in the Late-Ediacaran to Early Cambrian ocean was similar to that of $\mathrm{Mo}$, and confirms the validation of $\mathrm{V}$ isotopes in black shale as a global redox proxy. The $\mathrm{V}$ isotope fractionation is $\sim-0.7$ between anoxic sediments and seawater, and $\sim-0.4$ between euxinic sediment and seawater. Based on it, we reconstructed the seawater $\delta^{51} \mathrm{~V}$ variations from the Late-Ediacaran to Early Cambrian, which show a gradual elevation to the modern value [2]. This indicates that the extent of the global oceanic oxygenation increased from the Late-Ediacaran, and reached the modern-like level in the Early Cambrian, which may be benefical to the "Cambrian Exploration".

\section{Reference}

[1] Chen et al. (2015), Nat. Commun. 6, 7142.

[2] Wu et al. (2020), Geochim. Cosmochim. Acta, 284, 134155 . 